Yu-Tao Xiang ORCID iD: 0000-0002-2906-0029

\title{
Mobile Phone Addiction in Tibetan and Han Chinese adolescents
}

Running head: Mobile phone addiction in adolescents

Li Lu, PhD ${ }^{1 \#,}$

Dan-Dan Xu, PhD ${ }^{1,2 \#,}$

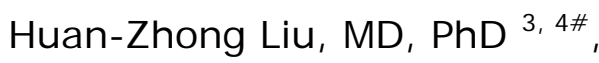

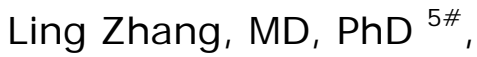

Chee H. Ng, MBBS, PhD ${ }^{6}$,

Gabor S. Ungvari, MD, PhD ${ }^{7,8}$,

Weng Tong Wu, Student ${ }^{9}$

Yifan Xiang, Student ${ }^{10}$

Feng-Rong $\mathrm{An}, \mathrm{PhD}^{5 *}$

Yu-Tao Xiang, MD, $\mathrm{PhD}^{1 *}$

This is the author manuscript accepted for publication and undergone full peer review but has not been through the copyediting, typesetting, pagination and proofreading process, which may lead to differences between this version and the Version of Record. Please cite this article as doi: 10.1002/ppc.12336.

This article is protected by copyright. All rights reserved. 
1. Unit of Psychiatry, Faculty of Health Sciences, University of Macau, Macao SAR, China;

2. Faculty of science, Harbin University, Heilongjiang province, China;

3. Department of Psychiatry, Chaohu Hospital of Anhui Medical University, Hefei, Anhui, China;

4. Anhui Psychiatric Center of Anhui Medical University, Hefei, Anhui, China;

5. The National Clinical Research Center for Mental Disorders, China \&Center of Depression, Beijing Institute for Brain Disorders \& Mood Disorders Center, Beijing Anding Hospital, Capital Medical University, Beijing, China;

6. Department of Psychiatry, University of Melbourne, Melbourne, Victoria, Australia;

7. University of Notre Dame Australia / Marian Centre, \& Graylands Hospital, Perth, Australia;

8. Division of Psychiatry, University of Western Australia Medical School, Perth, Australia;

9. Macau Chan Sui Ki Perpetual Help College, Macao SAR, China;

10. Macau Pui Ching Middle School, Macao SAR, China;

\# These authors contributed equally to this work.

* Address correspondence to Dr. Yu-Tao Xiang, 3/F, Building E12, Faculty of Health Sciences, University of Macau, Avenida da Universidade, Taipa, Macau SAR, China. Fax: +853-2288-2314; Phone: +853-8822-4223; E-mail: xyutly@gmail.com; or Dr. Feng-Rong An, Beijing Anding Hospital, Capital Medical University, Beijing, China. E-mail:afrylm@sina.com 


\section{Acknowledgements}

None.

\section{Sources of Funding}

The study was supported by the University of Macau

(MYRG2015-00230-FHS; MYRG2016-00005-FHS), National Key

Research \& Development Program of China (No. 2016YFC1307200),

Beijing Municipal Administration of Hospitals Clinical Medicine

Development of Special Funding Support (No.ZYLX201607) and Beijing

Municipal Administration of Hospitals' Ascent Plan (No. DFL20151801).

\section{Author Disclosure Statement}

The authors have no conflicts of interest to declare.

This article is protected by copyright. All rights reserved. 


\section{ABSTRACT}

PURPOSE: To compare mobile phone addiction (MPA) patterns between Tibetan and Han adolescents in China.

DESIGN AND METHODS: The study was carried out in two provinces of China. The Mobile Phone Addiction Scale (MPAS) was used to assess MPA.

FINDINGS: 705 Tibetan and 606 Han students participated in the study. The MPAS total score was $24.4 \pm 11.4$ in the whole sample; $27.3 \pm 10.8$ and 20.9 \pm 11.2 in Tibetan and Han students, respectively. Quality of life in the physical, psychological, social and environmental domains were negatively associated MPA.

PRACTICE IMPLICATIONS: Compared with Han students, Tibetan students were found to have more severe MPA. Given its negative impact on quality of life, appropriate measures for the prevention of MPA should be developed, particularly for Tibetan middle school students.

Key words: China, middle school students, mobile phone addiction, MPAS, quality of life 


\section{NTRODUCTION}

In the past decade, mobile phone use has become increasingly common in daily life. Mobile phone helps people maintain social network (Rettie, 2008), but its excessive use is associated with negative health issues, such as mobile phone addiction (MPA) and related somatic and psychological problems (Cerutti, Presaghi, Spensieri, Valastro, \& Guidetti, 2016; Cho et al., 2016; Coureau et al., 2014; Hillert et al., 2008; Kalafatakis, Bekiaridis-Moschou, Gkioka, \& Tsolaki, 2017; Korpinen \& Paakkonen, 2009; Liu et al., 2014; Moon, Kim, Kim, Lee, \& Lee, 2014).

The number of mobile phone users has increased from 0.39 billion in 2012 to 0.72 billion by June of 2017 in China, accounting for $72.2 \%$ in 2012 and $96.3 \%$ of the whole netizens in that year (CNNIC, 2017). Students were the largest group of the Chinese netizens, (CNNIC, 2017) and MPA in this population, particularly in middle school students, has gained much attention. MPA could negatively affect students' academic performance, and physical and mental well-being (Chen et al., 2016; Kim, Lee, \& Choi, 2015; Roberts, Yaya, \& Manolis, 2014; Roser, Schoeni, Foerster, \& Roosli, 2016). For example, MPA is negatively associated with self-control in college students but not with family structure and gender (Jiang \& Shi, 2016). Both interpersonal problems and negative 
emotions are positively associated with MPA in Chinese young adults Chen et al., 2016). In the US, mobile phone use was found to be positively associated with anxiety, but negatively associated with academic performance (GPA) (Lepp, Barkley, \& Karpinski, 2014). In Europe, adolescents' MPA was positively associated with adverse home and school environments (Roser et al., 2016).

Understanding the patterns of MPA and their associated factors is essential to develop appropriate preventive strategies. Considering that Internet additive behaviors are significantly associated with sociocultural and economic factors (Kuss, Griffiths, Karila, \& Billieux, 2014; Montag et al., 2015), patterns and associated factors of MPA should be examined separately in different populations. A recent meta-analysis found that the prevalence of Internet addition in Chinese university students was $11.3 \%$ ( $L i$ et al., 2018). The prevalence of MPA varied greatly across studies in China, ranging from $7.4 \%$ (Mei et al., 2018) to $21.3 \%$ (Long et al., 2016). Quality of life (QOL) is a comprehensive outcome measure in clinical practice and epidemiological research (Kaplan, 2002). However, no data on MPA and its relationship with QOL, particularly in ethnic minority adolescents in China, have been published. 
This study set out to compare the patterns of MPA between Tibetan and Han Chinese adolescents and explore their associations with socio-demographic characteristics and QOL.

\section{METHODS}

Settings and study time

This comparative survey was carried out between May and July 2017 in Qinghai and Anhui provinces (Lu et al., 2018). Anhui province is in east of China, with predominately Han Chinese population, while Qinghai province is in Tibetan Platea, with various ethnic minority populations, including Tibetan, Salars and Hui Chinese. The teaching system in middle schools and the sociocultural context differ between the two provinces.

Two public middle schools in each of the two provinces were selected on the basis of convenience sampling. All students in these schools were approached and invited to take part in this survey. Teaching staff distributed the written informed consents to students' parents, with the request of returning the signed informed consents within one week. Teaching staff also distributed the questionnaires to all students whose parents had provided written informed consent. The anonymously 
completed questionnaires were collected on the same day. Participation in the survey was entirely voluntary.

The research protocol was approved by the local Ethics panel. Following the local ethical requirements of epidemiological survey, all participating adolescents had to verbally agree to participate in this survey and their parents needed to provide written informed consent.

\section{Assessment tools}

Participating students' basic socio-demographic characteristics were recorded. The Mobile Phone Addiction Scale (MPAS) (Hong, Chiu, \& Huang, 2012) was used to assess the presence and severity of MPA. Based on the Young Internet Addiction Scale (Young, 1998), the MPAS is a self-reported questionnaire which showed satisfactory psychometric properties in Chinese populations (Chiu, Hong, \& Chiu, 2013). A higher score indicates more severe MPA. The Centre for Epidemiologic studies of Depression Symptom Scale was used to assess depressive symptoms (Radloff, 1991). Quality of life (QOL) was evaluated with the WHO Quality of Life, Brief Version (WHOQOL-BREF) (Fang \& Hao, 1999; WHO, 1998) that has 26 items covering four QOL domains: physical, psychological, social and environmental domains. 
Data analyses

The STATA Version 12.0 (Stata Corporation, College Station, Texas, USA) was used to analyze data. The comparisons between provinces in terms of socio-demographic characteristics, MPA and QOL were performed with Mann-Whitney U test, chi-square test, independent sample t-test, Kruskal-Wallis test, where applicable.

Multivariate linear regression analysis was used to examine the independent associations of MPA with geographic areas (i.e., Qinghai or Anhui province) and basic demographic characteristics. Furthermore, another multivariate linear regression analysis was performed to explore the contribution of MPA to QOL after adjusting for the variables that were associated with MPA in univariate analyses. Dummy variables were set for categorical variables. Multicollinearity was measured using the variance inflation factor (VIF) (O'Brien, 2007). Two-tailed tests were conducted with the significance level of 0.05 .

\section{RESULT}

Of the 1,462 students who had been approached, 1,311 (705 Tibetan and 606 Han) students and their parents/guardians provided informed consent and completed the assessment; the response rate was $89.7 \%$. 
The MPAS total score of the whole sample was $24.4 \pm 11.4 ; 27.3 \pm 10.8$ and $20.9 \pm 11.2$ in the Tibetan and Han students, respectively.

The socio-demographic data of the whole sample and separately by study sites are shown in Table 1. There were significant differences between the two sites in terms of age, grade, living conditions, religious beliefs, study pressure, perception of their body weight, age of the first mobile phone use and the CESD total score. After controlling for these variables in multiple linear regression analysis, Tibetan students had more severe MPA than Han students ( $b e t a=4.76, p<0.001 ; R^{2}=0.191$, $\mathrm{p}<0.001)$.

The unadjusted associations between socio-demographic characteristics and MPA are shown in Table 2. MPA was significantly associated with having religious beliefs, grade, study pressure, health status and body weight perception, relationships with classmates, teacher and family, age and CESD score. After controlling for covariates, having more severe depressive symptoms, religious beliefs, perception of being overweight and fair relationship with teachers were independently associated with MPA, which accounted for $19.1 \%$ of variance of the model $(p<0.001)$ (Table 3$)$. In addition, there were negative and significant associations between MPA and QOL in the This article is protected by copyright. All rights reserved. 
physical ( beta $=-0.04, p<0.001 ; R^{2}=0.302$ ), psychological (beta $=-0.04$, $p<0.001 ; R^{2}=0.287$ ), social (beta $\left.=-0.02, p=0.008 ; R^{2}=0.206\right)$ and environmental domains ( beta $=-0.02, p=0.001 ; R^{2}=0.212$ ).

\section{DISCUSSION}

To the best of our knowledge, this was the first study that compared patterns of MPA between Tibetan and Han adolescents in China. The mean score of MPAS in the whole sample was $24.4 \pm 11.4$, which was lower than the corresponding figure in a survey of university students in Taiwan. MPA was more severe in Tibetan $(27.3 \pm 10.8)$ than in Han Chinese students (20.9 \pm 11.2$)$. In China, the Law of on the Protection of Minors (2006 Revision) has forbidden minors from entering Internet cafes which are not allowed to be located near primary and secondary schools. However, the restricting Internet use in middle school students is difficult given the wide availability of the Internet through mobile phones, the availability of which could increase the risk of MPA.

Depressive symptoms were positively associated with MPA, which is consistent with previous findings (Augner \& Hacker, 2012; Chen, 2004; Elhai, Dvorak, Levine, \& Hall, 2017; Jeong \& Kim, 2005; Thomée, Härenstam, \& Hagberg, 2011). Compared to adults, adolescents are 
more likely to experience difficulties in interpersonal relationships and communication with others in life due to depressed mood and negative emotions Chen et al., 2016; Ha, Chin, Park, Ryu, \& Yu, 2008). Instead, they are more prone to cope with their communication difficulties and negative emotions by using mobile phones that provide them with a virtual and desirable world (Yen et al., 2009). In this study, having religious beliefs was positively associated with MPA. Two studies conducted in Turkey and Malaysia that examined the relationship between problematic Internet use and religious beliefs (Charlton, Soh, Ang, \& Chew, 2013; Ekşi \& Çiftçi, 2017) reported conflicting results. The relationship between religious beliefs and MPA needs further research.

The perception of being overweight was associated with a higher risk of MPA. People particularly adolescents who are overweight are more likely to have low self-esteem (Mendelson \& White, 1985; Mirza, Davis, \& Yanovski, 2005; Pierce \& Wardle, 1997; Strauss, 2000), which in turn could increase the risk of addictive behaviors (Bianchi \& Phillips, 2005; Kim, 2016; Leung, 2008) including MPA. Self-esteem is another factor that could moderate the association between depression and MPA (Kim, 2016). However, the role of self-esteem, which was not measured 
in this survey, in the association between being overweight and MPA warrants further study.

Mobile phone use promotes and maintains personal relationships (Rettie, 2008), especially in adolescents who use mobile phones appropriately (Campbell, 2005). In this study, having fair relationship with teachers was positively associated with MPA, while the association between MPA and fair association with classmates showed a trend of significance $(p=0.07)$. This is consistent with an earlier study of Chinese adolescents that found student relationships negatively associated with mobile phone addiction (Wang et al., 2017). Previous studies found that female middle school and university students (Beranuy, Oberst, Carbonell, \& Chamarro, 2009; Chiu et al., 2013; Roberts et al., 2014; Roser et al., 2016; Warzecha \& Pawlak, 2017) and younger age (Augner \& Hacker, 2012; Bianchi \& Phillips, 2005) had more severe MPA, which was not confirmed in this study.

The findings of this survey should be interpreted with caution due to several methodological limitations. First, important variables related to MPA, such as whether all participants had a smartphone, length of having a mobile phone, mean duration of mobile phone use, physical exercise and parental education level, were not recorded. Second, this This article is protected by copyright. All rights reserved. 
was a cross-sectional survey, therefore the causality between MPA and other variables could not be confirmed. Third, due to logistic reasons, only students from four public schools were selected using convenience sampling, thus the findings could be not generalized in all students in both provinces. Fourth, students who declined to participate in the study did not provide written informed consent, therefore according to local ethical regulations, their demographic data could not be collected and compared with those of the participants.

In conclusion, measured with MPAS, Tibetan adolescents were found to have more severe MPA than Han Chinese adolescents. Due to the negative influence of MPA on health and social relations, appropriate measures for the prevention of MPA should be developed for this population. 


\section{References}

Augner, C., \& Hacker, G. W. (2012). Associations between problematic mobile phone use and psychological parameters in young adults. Int J Public Health, 57(2), 437-441.

doi: $10.1007 /$ s00038-011-0234-z

Beranuy, , Oberst, U, Carbonell, X, \& Chamarro, A. (2009). Problematic Internet and mobile phone use and clinical symptoms in college students: The role of emotional intelligence. Computers in Human Behavior, 25(5), 1182-1187.

doi: https://doi.org/10.1016/j.chb.2009.03.001

Bianchi, A., \& Phillips, J. G. (2005). Psychological predictors of problem mobile phone use. Cyberpsychol Behav, 8(1), 39-51. doi: $10.1089 /$ cpb. 2005.8.39

Campbell, M A. (2005). The impact of the mobile phone on young people's social life. Social Change in the 21st Century Conference. doi: 10.3233/ wor-172678

Cerutti, R., Presaghi, F., Spensieri, V., Valastro, C., \& Guidetti, V. (2016). The Potential I mpact of I nternet and Mobile Use on Headache and Other Somatic Symptoms in Adolescence. A Population-Based 
Cross-Sectional Study. Headache, 56(7), 1161-1170.

doi: $10.1111 /$ head. 12840

Charlton, J. P., Soh, P. C. H., Ang, P. H., \& Chew, K.W. (2013). Religiosity, adolescent Internet usage motives and addiction. Information, Communication \& Society, 16(10), 1619-1638.

doi: 10.1080/1369118X.2012.735251

Chen, Li, Yan, Zheng, Tang, Wenjie, Yang, Fuyin, Xie, Xiaodan, \& He, Jincai. (2016). Mobile phone addiction levels and negative emotions among Chinese young adults: The mediating role of interpersonal problems. Computers in Human Behavior, 55, 856-866. doi: 10.1016/j.chb.2015.10.030

Chen, Y. F. (2004). The relationship of mobile phone use to addiction and depression amongst American college students. Moblie Communication and Social Change, 10, 344-352.

doi: 10.1016/j.jadohealth.2004.02.033

Chiu, S. I., Hong, F. Y., \& Chiu, S. L. (2013). An Analysis on the Correlation and Gender Difference between College Students' Internet Addiction and Mobile Phone Addiction in Taiwan. ISRN Addict, 2013, 360607. doi: 10.1155/2013/360607 
Cho, Y. M., Lim, H. J., Jang, H., Kim, K., Choi, J. W., Shin, C., . . Kim, N. (2016). A follow-up study of the association between mobile phone use and symptoms of ill health. Environ Health Toxicol, 32, e2017001. doi: 10.5620/eht.e2017001

CNNIC. (2017). The 40th China Statistical Report on Internet Development. Office of the Central Leading Group for Cyberspace Affairs. doi: 10.1089/cyber.2012.0482

Coureau, G., Bouvier, G., Lebailly, P., Fabbro-Peray, P., Gruber, A., Leffondre, K., . . Baldi, I. (2014). Mobile phone use and brain tumours in the CERENAT case-control study. Occup Environ Med, 71(7), 514-522. doi: 10.1136/oemed-2013-101754

Ekşi, H., \& Çiftçi, M. (2017). Predicting High School Students' Problematic Internet Use in Terms of Religious Beliefs and Moral Maturity. Addicta: The Turkish J ournal on Addictions(4), 181-206. doi: 10.1016/j.psychres.2008.01.015

Elhai, J. D., Dvorak, R. D., Levine, J. C., \& Hall, B. J. (2017). Problematic smartphone use: A conceptual overview and systematic review of relations with anxiety and depression psychopathology. Journal of 
Affective Disorders, 207, 251-259.

doi: 10.1016/j.jad.2016.08.030

Fang, J. Q., \& Hao, Y. A. (1999). Reliability and Validity for Chinese Version of WHO Quality of Life Scale. Chinese Mental Health Journal, 13(4), 203-209.

Ha, J. H., Chin, B., Park, D. H., Ryu, S. H., \& Yu, J. (2008). Characteristics of excessive cellular phone use in Korean adolescents. Cyberpsychol Behav, 11(6), 783-784.

doi: $10.1089 /$ cpb. 2008.0096

Hillert, L., Akerstedt, T., Lowden, A., Wiholm, C., Kuster, N., Ebert, S., . . Arnetz, B. B. (2008). The effects of $884 \mathrm{MHz}$ GSM wireless communication signals on headache and other symptoms: an experimental provocation study. Bioelectromagnetics, 29(3), 185-196. doi: 10.1002/bem.20379

Hong, Fu Yuan, Chiu, Shao I., \& Huang, Der Hsiang. (2012). A model of the relationship between psychological characteristics, mobile phone addiction and use of mobile phones by Taiwanese university female students. Computers in Human Behavior, 28(6), 2152-2159. doi: https://doi.org/10.1016/j.chb.2012.06.020 
Jeong, J. Y., \& Kim, D. H. (2005). A study on the addicted use of mobile phone among the high school students. Korean J ournal of Epidemiology, 27(1), 140-153.

doi: $10.1016 / j$.jadohealth.2004.02.033

Jiang, Z., \& Shi, M. (2016). Prevalence and co-occurrence of compulsive buying, problematic Internet and mobile phone use in college students in Yantai, China: relevance of self-traits. BMC Public Health, 16(1), 1211. doi: 10.1186/s12889-016-3884-1

Kalafatakis, F., Bekiaridis-Moschou, D., Gkioka, E., \& Tsolaki, M. (2017). Mobile phone use for 5 minutes can cause significant memory impairment in humans. Hell J Nucl Med, 20 Suppl, 146-154.

Kaplan, R. M. (2002). Quality of life: an outcomes perspective. Archives of Physical Medicine and Rehabilitation, 83(12 Suppl 2), S44-50.

Kim, Minkyeong. (2016). The Relationship between Cellular Phone Addiction and Impulsiveness, Depression, and Self-esteem of Multicultural Adolescents. Indian J ournal of Science and Technology, 9(35), e15. doi: 10.1089/cyber.2014.0139

Kim, R., Lee, K. J., \& Choi, Y. J. (2015). Mobile Phone Overuse Among Elementary School Students in Korea: Factors Associated With 
Mobile Phone Use as a Behavior Addiction. J Addict Nurs, 26(2), 81-85. doi: 10.1097/jan.0000000000000074

Korpinen, L. H., \& Paakkonen, R. J. (2009). Self-report of physical symptoms associated with using mobile phones and other electrical devices. Bioelectromagnetics, 30(6), 431-437. doi: $10.1002 /$ bem. 20500

Kuss, D. J., Griffiths, M. D., Karila, L., \& Billieux, J. (2014). Internet addiction: a systematic review of epidemiological research for the last decade. Current Pharmaceutical Design, 20(25), 4026-4052.

Lepp, A, Barkley, J E., \& Karpinski, A C. (2014). The relationship between cell phone use, academic performance, anxiety, and Satisfaction with Life in college students. Computers in Human Behavior, 31, 343-350. doi: https://doi.org/10.1016/j.chb.2013.10.049

Leung, L. (2008). Linking Psychological Attributes to Addiction and Improper Use of the Mobile Phone among Adolescents in Hong Kong. Journal of Children and Media, 2(2), 93-113. doi: $10.1080 / 17482790802078565$

Li, L., Xu, D.D., Chai, J.X., Wang, D., Li, L., Zhang, L., . . Xiang, Y.T. . (2018). Prevalence of Internet addiction disorder in Chinese 
university students: a comprehensive meta-analysis. J Behav Addict. doi: 10.1556/2006.6.2017.079

Liu, K., Li, Y., Zhang, G., Liu, J., Cao, J., Ao, L., \& Zhang, S. (2014). Association between mobile phone use and semen quality: a systemic review and meta-analysis. Andrology, 2(4), 491-501. doi: 10.1111/j.2047-2927.2014.00205.x

Long, J., Liu, T. Q., Liao, Y. H., Qi, C., He, H. Y., Chen, S. B., \& Billieux, J. (2016). Prevalence and correlates of problematic smartphone use in a large random sample of Chinese undergraduates. BMC Psychiatry, 16(1), 408. doi:10.1186/s12888-016-1083-3

Lu, L., Xu, D. D., Liu, H. Z., Zhang, L., Ng, C. H., Ungvari, G. S., . . Xiang, Y. T. (2018). Internet addiction in Tibetan and Han Chinese middle school students: prevalence, demographics and quality of life. Psychiatry Research, 268, 131-136. doi: 10.1016/j.psychres.2018.07.005

Mei, S., Chai, J., Wang, S. B., Ng, C. H., Ungvari, G. S., \& Xiang, Y. T. (2018). Mobile Phone Dependence, Social Support and Impulsivity in Chinese University Students. Int J Environ Res Public Health, 15(3). doi: 10.3390/ijerph15030504 
Mendelson, B. K., \& White, D. R. (1985). Development of self-body-esteem in overweight youngsters. Developmental Psychology, 21(1), 90-96. doi: 10.1089/cyber.2014.0139

Mirza, N. M., Davis, D., \& Yanovski, J. A. (2005). Body dissatisfaction, self-esteem, and overweight among inner-city Hispanic children and adolescents. J Adolesc Health, 36(3), 267.e216-220. doi: $10.1016 /$ j.jadohealth.2004.02.033

Montag, C., Bey, K., Sha, P., Li, M., Chen, Y. F., Liu, W. Y., . . Reuter, M. (2015). Is it meaningful to distinguish between generalized and specific Internet addiction? Evidence from a cross-cultural study from Germany, Sweden, Taiwan and China. Asia Pac Psychiatry, 7(1), 20-26. doi: 10.1111/appy.12122

Moon, I. S., Kim, B. G., Kim, J., Lee, J. D., \& Lee, W. S. (2014). Association between vestibular schwannomas and mobile phone use. Tumour Biol, 35(1), 581-587. doi: $10.1007 /$ s13277-013-1081-8

O'brien, R M. (2007). A Caution Regarding Rules of Thumb for Variance Inflation Factors. Quality \& Quantity, 41(5), 673-690. doi: 10.1007/s11135-006-9018-6 
Pierce, J. W., \& Wardle, J. (1997). Cause and effect beliefs and self-esteem of overweight children. J Child Psychol Psychiatry, $38(6), 645-650$.

Radloff, L S. (1991). The use of the Center for Epidemiologic Studies Depression Scale in adolescents and young adults. Journal of Youth and Adolescence, 20(2), 149-166. doi: 10.1007/bf01537606

Rettie, R. (2008). Mobile Phones as Network Capital: Facilitating Connections. Mobilities, 3(2), 291-311. doi: $10.1080 / 17450100802095346$

Roberts, J. A., Yaya, L. H., \& Manolis, C. (2014). The invisible addiction: cell-phone activities and addiction among male and female college students. J Behav Addict, 3(4), 254-265. doi: 10.1556/jba.3.2014.015

Roser, K., Schoeni, A., Foerster, M., \& Roosli, M. (2016). Problematic mobile phone use of Swiss adolescents: is it linked with mental health or behaviour? Int J Public Health, 61(3), 307-315. doi: $10.1007 /$ s00038-015-0751-2 
S Strauss, R. (2000). Childhood Obesity and Self-Esteem. Pediatrics, 105(1), e15. doi: 10.1089/cyber.2014.0139

Thomée, S, Härenstam, A, \& Hagberg, M. (2011). Mobile phone use and stress, sleep disturbances, and symptoms of depression among young adults - a prospective cohort study. BMC Public Health, 11(1), 66. doi: 10.1186/1471-2458-11-66

Wang, P., Zhao, M., Wang, X., Xie, X., Wang, Y., \& Lei, L. (2017). Peer relationship and adolescent smartphone addiction: The mediating role of self-esteem and the moderating role of the need to belong. J Behav Addict, 6(4), 708-717. doi:10.1556/2006.6.2017.079

Warzecha, K., \& Pawlak, A. (2017). Pathological use of mobile phones by secondary school students. Archives of Psychiatry and Psychotherapy, 1, 27-36. doi:10.1016/j.jadohealth.2004.02.033

WHO. (1998). Development of the World Health Organization WHOQOL-BREF quality of life assessment. The WHOQOL Group. Psychol Med, 28(3), 551-558.

Yen, C. F., Tang, T. C., Yen, J. Y., Lin, H. C., Huang, C. F., Liu, S. C., \& Ko, C. H. (2009). Symptoms of problematic cellular phone use, functional impairment and its association with depression among This article is protected by copyright. All rights reserved. 
adolescents in Southern Taiwan. J Adolesc, 32(4), 863-873. doi: 10.1016/j. adolescence.2008.10.006

Young, K. S. (1998). Internet Addiction: The Emergence of a New Clinical Disorder. CyberPsychology \& Behavior, 1, 237-244. doi: 10.1089/cyber.2014.0139

Table 1. Sociodemographic and clinical characteristics of the whole sample and by study site

\begin{tabular}{|c|c|c|c|c|c|c|c|c|c|}
\hline & \multicolumn{2}{|c|}{$\begin{array}{l}\text { Whole } \\
\text { sample } \\
(n=1,311)\end{array}$} & \multicolumn{2}{|c|}{$\begin{array}{c}\text { Anhui } \\
\text { province } \\
(n=606)\end{array}$} & \multicolumn{2}{|c|}{$\begin{array}{c}\text { Qinghai } \\
\text { province }^{a} \\
(n=705)\end{array}$} & \multicolumn{3}{|c|}{ Statistics } \\
\hline & Mean & SD & Mean & SD & Mean & SD & z & df & $\mathbf{P}$ \\
\hline Age (year) & 15.1 & 1.9 & 14.2 & 1.7 & 15.9 & 1.7 & -15.8 & $---{ }^{b}$ & $<0.001$ \\
\hline $\mathrm{CESD}^{\mathrm{c}}$ total & 27.1 & $\begin{array}{c}11 . \\
9\end{array}$ & 36.9 & 7.9 & 18.7 & 7.6 & 28.5 & $--^{b}$ & $<0.001$ \\
\hline $\begin{array}{l}\text { Age of first mobile phone } \\
\text { use }\end{array}$ & 14.0 & 15.8 & 14.3 & 17.6 & 13.8 & 14.2 & -4.7 & $---b$ & $<0.001$ \\
\hline MPA total ${ }^{d}$ & 24.4 & 11.4 & 20.9 & 11.2 & 27.3 & 10.8 & -11.4 & $---b$ & $<0.001$ \\
\hline
\end{tabular}

This article is protected by copyright. All rights reserved. 


\begin{tabular}{|c|c|c|c|c|c|c|c|c|c|}
\hline & $\mathbf{N}$ & $\%$ & $\mathbf{N}$ & $\%$ & $\mathbf{N}$ & $\%$ & $x^{2}$ & df & $\mathbf{P}$ \\
\hline Female & 605 & 46.1 & 265 & 43.7 & 340 & 48.2 & 2.7 & 1 & 0.10 \\
\hline Having religious beliefs & 221 & 16.9 & 75 & 12.4 & 146 & 20.7 & 16.1 & 1 & $<0.001$ \\
\hline One child family & 630 & 48.1 & 303 & 50.0 & 327 & 46.4 & 1.7 & 1 & 0.19 \\
\hline Junior middle school & 621 & 47.4 & 412 & 68.0 & 209 & 29.6 & 192.2 & 1 & $<0.001$ \\
\hline Living with family & 1277 & 97.4 & 580 & 95.7 & 697 & 98.9 & 12.8 & 1 & $<0.001$ \\
\hline Study pressure & & & & & & & 7.4 & 2 & 0.02 \\
\hline Low & 65 & 5.0 & 33 & 5.4 & 32 & 4.5 & & & \\
\hline Fair & 829 & 63.2 & 403 & 66.5 & 426 & 60.4 & & & \\
\hline High & 417 & 31.8 & 170 & 28.1 & 247 & 35.0 & & & \\
\hline $\begin{array}{l}\text { Personal health status } \\
\text { perception }\end{array}$ & & & & & & & 0.5 & 2 & 0.78 \\
\hline $\mathrm{Bad}$ & 66 & 5.0 & 28 & 4.6 & 38 & 5.4 & & & \\
\hline Fair & 720 & 54.9 & 337 & 55.6 & 383 & 54.3 & & & \\
\hline Good & 525 & 40.0 & 241 & 39.8 & 284 & 40.3 & & & \\
\hline
\end{tabular}

This article is protected by copyright. All rights reserved. 


\begin{tabular}{|c|c|c|c|c|c|c|c|c|c|}
\hline Body weight perception & & & & & & & 8.2 & 2 & 0.02 \\
\hline Underweight & 178 & 13.6 & 77 & 12.7 & 101 & 14.3 & & & \\
\hline Fair & 809 & 61.7 & 357 & 58.9 & 452 & 64.1 & & & \\
\hline Overweight & 324 & 24.7 & 172 & 28.4 & 152 & 21.6 & & & \\
\hline $\begin{array}{l}\text { Relationship with } \\
\text { classmates }\end{array}$ & & & & & & & 2.2 & 2 & 0.33 \\
\hline Poor & 40 & 3.1 & 20 & 3.3 & 20 & 2.8 & & & \\
\hline Fair & 580 & 44.2 & 255 & 42.1 & 325 & 46.1 & & & \\
\hline Good & 691 & 52.7 & 331 & 54.6 & 360 & 51.1 & & & \\
\hline Relationship with Teacher & & & & & & & 0.5 & 2 & 0.76 \\
\hline Poor & 58 & 4.4 & 25 & 4.1 & 33 & 4.7 & & & \\
\hline Fair & 836 & 63.8 & 383 & 63.2 & 453 & 64.3 & & & \\
\hline Good & 417 & 31.8 & 198 & 32.7 & 219 & 31.1 & & & \\
\hline Relationship with Family & & & & & & & 0.9 & 2 & 0.64 \\
\hline Poor & 28 & 2.1 & 11 & 1.8 & 17 & 2.4 & & & \\
\hline Fair & 307 & 23.4 & 138 & 22.8 & 169 & 24.0 & & & \\
\hline Good & 976 & 74.5 & 457 & 75.4 & 519 & 73.6 & & & \\
\hline
\end{tabular}

This article is protected by copyright. All rights reserved. 


\begin{tabular}{|c|c|c|c|c|c|c|c|c|c|}
\hline $\begin{array}{l}\text { Family financial status } \\
\text { perception }\end{array}$ & 89 & 6.8 & 35 & 5.8 & 54 & 7.7 & & & \\
\hline Poor & 1111 & 84.7 & 521 & 86.0 & 590 & 83.7 & & & \\
\hline Fair & 111 & 8.5 & 50 & 8.3 & 61 & 8.7 & & & \\
\hline Good & & & & & & & & & \\
\hline
\end{tabular}

Bold values: $p<0.05$

${ }^{a}$ Including $563 \mathrm{Han}, 60 \mathrm{Hui}, 36$ Tibetan and 46 other ethnic minority Chinese middle school students in Tibetan area in Qinghai province

${ }^{\mathrm{b}}$ Mann-Whitney text;

${ }^{\mathrm{c}}$ CESD: 20-item Centre for Epidemiologic studies of depression Symptom Scale

${ }^{\mathrm{d}}$ MPA: Mobile phone addiction

Table 2. Crude associations between basic demographic characteristics and MPA in Chinese middle school students

\begin{tabular}{|l|l|c|c|c|c|}
\hline \multirow{2}{*}{ Variables } & \multirow{2}{*}{ category } & \multicolumn{2}{|c|}{ MPA (n=1,311) } & \multicolumn{2}{c|}{ Statistics } \\
\hline \multirow{2}{*}{ Gender } & & Mean & SD & $Z^{\text {a }}$ & P \\
& Female & 24.0 & 11.1 & -0.9 & 0.36 \\
\cline { 2 - 5 } & Male & 24.7 & 11.7 & & \\
\hline \multirow{2}{*}{ Having religious beliefs } & No & 23.9 & 11.2 & -3.5 & $<0.001$ \\
\cline { 2 - 5 } & Yes & 26.9 & 12.0 & & \\
\hline
\end{tabular}

This article is protected by copyright. All rights reserved. 


\begin{tabular}{|c|c|c|c|c|c|}
\hline \multirow[t]{2}{*}{ One child family } & No & 24.6 & 11.5 & \multirow[t]{2}{*}{0.7} & \multirow[t]{2}{*}{0.50} \\
\hline & Yes & 24.1 & 11.3 & & \\
\hline \multirow[t]{2}{*}{ Grade type } & Junior & 21.3 & 10.8 & \multirow[t]{2}{*}{10.0} & \multirow[t]{2}{*}{$<0.001$} \\
\hline & Senior & 27.2 & 11.3 & & \\
\hline \multirow[t]{2}{*}{ Living with family } & No & 24.8 & 13.2 & \multirow[t]{2}{*}{-0.1} & \multirow[t]{2}{*}{0.89} \\
\hline & Yes & 24.4 & 11.4 & & \\
\hline \multirow[t]{3}{*}{ Area } & Anhui & 20.9 & 11.2 & \multirow[t]{2}{*}{-11.4} & \multirow[t]{2}{*}{$<0.001$} \\
\hline & Qinghai & 27.3 & 10.8 & & \\
\hline & & Mean & SD & $\mathrm{H}^{\mathrm{b}}$ & $\mathbf{P}$ \\
\hline \multirow[t]{3}{*}{ Study pressure } & Little & 20.7 & 11.7 & \multirow[t]{3}{*}{27.9} & \multirow[t]{3}{*}{$<0.001$} \\
\hline & Fair & 23.6 & 11.2 & & \\
\hline & High & 26.5 & 11.5 & & \\
\hline \multirow{3}{*}{$\begin{array}{l}\text { Personal health status } \\
\text { perception }\end{array}$} & Poor & 28.2 & 13.4 & \multirow[t]{3}{*}{33.5} & \multirow[t]{3}{*}{$<0.001$} \\
\hline & Fair & 25.5 & 11.3 & & \\
\hline & Good & 22.3 & 11.0 & & \\
\hline Body weight & Underweight & 24.0 & 11.5 & 13.8 & 0.001 \\
\hline
\end{tabular}

This article is protected by copyright. All rights reserved. 


\begin{tabular}{|c|c|c|c|c|c|}
\hline \multirow[t]{2}{*}{ perception } & Fair & 23.6 & 11.0 & & \\
\hline & Overweight & 26.6 & 12.2 & & \\
\hline Relationship with & Poor & 30.4 & 11.5 & \multirow[t]{3}{*}{24.4} & \multirow[t]{3}{*}{$<0.001$} \\
\hline \multirow{2}{*}{ classmates } & Fair & 25.4 & 11.7 & & \\
\hline & Good & 23.2 & 11.0 & & \\
\hline \multirow[t]{3}{*}{ Relationship with } & Poor & 26.6 & 12.4 & \multirow[t]{3}{*}{44.6} & \multirow[t]{3}{*}{$<0.001$} \\
\hline & Fair & 25.7 & 11.5 & & \\
\hline & Good & 21.4 & 10.5 & & \\
\hline \multirow[t]{3}{*}{ Relationship with } & Poor & 30.3 & 13.3 & \multirow[t]{3}{*}{25.2} & \multirow[t]{3}{*}{$<0.001$} \\
\hline & Fair & 26.7 & 11.7 & & \\
\hline & Good & 23.5 & 11.1 & & \\
\hline \multirow{4}{*}{$\begin{array}{l}\text { Family financial status } \\
\text { perception }\end{array}$} & Poor & 26.9 & 12.8 & \multirow[t]{3}{*}{3.9} & \multirow[t]{3}{*}{0.14} \\
\hline & Fair & 24.2 & 11.3 & & \\
\hline & Good & 23.7 & 11.4 & & \\
\hline & & Mean & SD & $r^{c}$ & $\mathbf{P}$ \\
\hline Age (year) & --- & 24.4 & 11.4 & 0.28 & $<0.001$ \\
\hline
\end{tabular}

This article is protected by copyright. All rights reserved. 


\begin{tabular}{|l|c|c|c|c|c|}
\hline CESD total score & --- & --- & --- & -0.11 & $<0.001$ \\
\hline Age of MP use first & --- & --- & --- & .0 .05 & 0.06 \\
\hline Physical QOL & --- & --- & --- & -0.32 & $<0.001$ \\
\hline Psychological QOL & --- & --- & --- & -0.24 & $<0.001$ \\
\hline Social QOL & --- & --- & --- & -0.17 & $<0.001$ \\
\hline Environmental QOL & --- & --- & --- & -0.16 & $<0.001$ \\
\hline
\end{tabular}

${ }^{\mathrm{a}}$ Mann-Whitney test; ${ }^{\mathrm{b}}$ Kruskal-Wallis test. ${ }^{\mathrm{c}}$ Spearman test.

MPA: Mobile phone addiction; $C E S D=20$-item Centre for Epidemiologic studies of Depression Symptom Scale; QoL: quality of life

Table 3. Independent associations between demographic characteristics and MPA in Chinese middle school students

\begin{tabular}{|l|c|c|c|c|}
\hline & \multirow{2}{*}{ Coefficient } & \multicolumn{2}{|c|}{ P value } & \multicolumn{2}{|c|}{$95 \%$ Cl } \\
\cline { 3 - 5 } & & & Lower & Upper \\
\hline Age (year) & & & -0.29 & 0.90 \\
\hline CESD total & 0.31 & 0.31 & 0.16 & 0.32 \\
\hline Having religious beliefs & 0.24 & $<0.001$ & 0.28 & 3.32 \\
\hline
\end{tabular}

This article is protected by copyright. All rights reserved. 


\begin{tabular}{|c|c|c|c|c|}
\hline Grade type / Senior & 1.89 & 0.09 & -0.32 & 4.10 \\
\hline \multicolumn{5}{|l|}{ Study pressure } \\
\hline Low & --- & 1.0 & --- & --- \\
\hline Fair & 1.59 & 0.24 & -1.06 & 4.23 \\
\hline High & 2.00 & 0.16 & -0.78 & 4.78 \\
\hline \multicolumn{5}{|c|}{ Personal health status perception } \\
\hline Poor & --- & 1.0 & --- & --- \\
\hline Fair & 0.49 & 0.72 & -2.22 & 3.19 \\
\hline Good & -1.39 & 0.34 & -4.20 & 1.43 \\
\hline \multicolumn{5}{|c|}{ Body weight perception } \\
\hline Underweight & --- & 1.0 & --- & --- \\
\hline Fair & 0.94 & 0.28 & -0.77 & 2.65 \\
\hline Overweight & 2.89 & 0.003 & 0.99 & 4.80 \\
\hline \multicolumn{5}{|c|}{ Relationship with classmates } \\
\hline Poor & --- & 1.0 & --- & --- \\
\hline Fair & -3.37 & 0.07 & -6.96 & 0.22 \\
\hline
\end{tabular}

This article is protected by copyright. All rights reserved. 


\begin{tabular}{|l|c|c|c|c|}
\hline Good & -2.56 & 0.17 & -6.21 & 1.09 \\
\hline Relationship with teacher & & & & \\
\hline Poor & --- & 1.0 & --- & --- \\
\hline Fair & 3.16 & 0.04 & 0.19 & 6.14 \\
\hline Good & 0.43 & 0.79 & -2.75 & 3.61 \\
\hline Relationship with family & --- & 1.0 & --- & --- \\
\hline Poor & -7.60 & 0.21 & -19.51 & 4.31 \\
\hline Fair & -2.28 & 0.27 & -6.31 & 1.74 \\
\hline Good & & 0.77 & -4.72 & 3.49 \\
\hline Constant & & & & \\
\hline
\end{tabular}

Adjusted $\mathrm{R}^{2}=0.191, \mathrm{p}<0.001$; bolded values: $\mathrm{p}<0.05$; study site has been controlled for as a covariate. CESD: 20-item Centre for Epidemiologic studies of Depression Symptom Scale

This article is protected by copyright. All rights reserved. 


\section{University Library}

\section{- M M N E R VA A gateway to Melbourne's research publications}

Minerva Access is the Institutional Repository of The University of Melbourne

Author/s:

Lu, L;Xu, D-D;Liu, H-Z;Zhang, L;Ng, CH;Ungvari, GS;Wu, WT;Xiang, Y-F;An, F-R;Xiang, Y-T

Title:

Mobile phone addiction in Tibetan and Han Chinese adolescents

Date:

2019-07-01

Citation:

Lu, L., Xu, D. -D., Liu, H. -Z., Zhang, L., Ng, C. H., Ungvari, G. S., Wu, W. T., Xiang, Y. F., An, F. -R. \& Xiang, Y. -T. (2019). Mobile phone addiction in Tibetan and Han Chinese adolescents. PERSPECTIVES IN PSYCHIATRIC CARE, 55 (3), pp.438-444. https:// doi.org/10.1111/ppc.12336.

Persistent Link:

http://hdl.handle.net/11343/284837 